\title{
Serum Immunoglobulin Free Light Chain Increased
}

National Cancer Institute

\section{Source}

National Cancer Institute. Serum Immunoglobulin Free Light Chain Increased. NCI

Thesaurus. Code C82435.

A laboratory test result indicating higher than normal levels of immunoglobulin free light chain in the serum. 